\title{
Iwona Wilk
}

Politechnika Łódzka

e-mail: iwona.wilk@p.lodz.pl

\section{DZIALALNOŚĆ MARKETINGOWA GOSPODARSTW EKOAGROTURYSTYCZNYCH W POLSCE}

\section{MARKETING ACTIVITIES OF ECO-AGRITOURISM FARMS IN POLAND}

DOI: $10.15611 /$ pn.2018.535.18

JEL Classification: M31

Streszczenie: Istotną formą realizacji idei zrównoważonego rozwoju w turystyce jest ekoagroturystyka, czyli działalność agroturystyczna prowadzona w ekologicznym gospodarstwie rolnym. Celem artykułu jest przedstawienie specyfiki działan marketingowych gospodarstw ekoagroturystycznych w świetle oczekiwań ekoagroturystów, a także sformułowanie dla nich rekomendacji w obszarze realizacji proekologicznej aktywności rynkowej. Badania zostały przeprowadzone w roku 2012 oraz w roku 2017 i objęły gospodarstwa ekoagroturystyczne w Polsce oraz klientów tych gospodarstw. W celu pozyskania informacji od respondentów wykorzystano metodę wywiadu. W świetle badań można stwierdzić, że klienci gospodarstw ekoagroturystycznych oczekują oferty usługowej uwzględniającej aspekt proekologiczny w możliwie najszerszym zakresie, a także są skłonni przyczyniać się do kształtowania jej proekologicznych cech, oceniając ją i formułując swoje propozycje.

Słowa kluczowe: ekoagroturystyka, marketing ekologiczny, oczekiwania klientów, działalność marketingowa.

Summary: An important form of sustainable development idea implementation in tourism is eco-agritourism defined as agritourism activity carried out on an organic farm. The aim of this article is to present the marketing activities of eco-agritourism farms in the light of eco-agritourists' expectations and to formulate recommendations for these farms in the area of pro-ecological market activity implementation. The study was carried out in 2012 and in 2017 on eco-agritourism farms in Poland and on customers of these farms. In order to obtain information from respondents, the interview method was used. In the light of research, it can be stated that customers of eco-agritourism farms expect services taking into account the ecological aspect to the fullest extent possible and they are willing to contribute to the development of pro-ecological features of those services, evaluating them and formulating their proposals.

Keywords: eco-agritourism, green marketing, customers' expectations, marketing activity. 


\section{Wstęp}

Sprzyjająca rozwojowi zrównoważonemu polityka państwa, zdeterminowana zaleceniami Unii Europejskiej w tym zakresie, stwarza podatny grunt dla działalności ekologicznych gospodarstw rolnych w obszarze ekoagroturystyki z uwzględnieniem przez nie proekologicznych działań marketingowych. Ekoagroturystyka, czyli połączenie agroturystyki z ekologicznymi metodami produkcji żywności, jest kierunkiem turystyki zrównoważonej, zyskującym coraz większą popularność. Ekoagroturystyka jest to działalność agroturystyczna realizowana w ekologicznym gospodarstwie rolnym [Privitera 2010]. Ekologiczne gospodarstwo rolne natomiast to takie gospodarstwo, które prowadzi produkcję ekologiczną, czyli stosuje ogólny system zarządzania gospodarstwem, łączący najkorzystniejsze dla środowiska praktyki, wysoki stopień różnorodności biologicznej, ochronę zasobów naturalnych, stosowanie wysokich standardów dotyczących dobrostanu zwierząt i metodę produkcji odpowiadającą wymaganiom tych konsumentów, którzy preferują wyroby wytwarzane przy użyciu substancji naturalnych i naturalnych procesów [Rozporządzenie Rady (WE) nr 834/2007]. Potwierdzeniem prowadzenia ekologicznej produkcji rolnej jest posiadanie certyfikatu ekologicznego wydanego przez jedną z upoważnionych jednostek certyfikujących. M. Jalinik [2009, s. 64] definiuje ekoagroturystykę szerzej, jako wypoczynek w gospodarstwie uprawiającym użytki rolne i produkującym żywność metodami ekologicznymi lub przestawiającymi się na rolnictwo ekologiczne, określanym jako gospodarstwo ekoagroturystyczne.

Wzrastająca świadomość ekologiczna polskich nabywców żywności powoduje, że coraz częściej kupują oni zdrowe, nieprzetworzone technologicznie produkty, a chęć czerpania korzyści z czystego środowiska sprawia, że decydują się na wypoczynek z dala od miast, przyczyniając się do rozwoju turystyki na obszarach wiejskich [Czerwińska-Jaśkiewicz 2013, s. 17; Romankiewicz, Krupa 2013; Sikora, Wartecka-Ważyńska 2013, s. 23-24 ]. Według E. Pałki [2015, s. 32] turystyka na terenach wiejskich powinna sprzyjać poprawie jakości życia społeczności lokalnej, zapewniać gościom odpowiedniej jakości wypoczynek oraz nie wywoływać dewastacji środowiska. Ekoagroturystyka otwiera zatem możliwości tworzenia nowych miejsc pracy i generowania dodatkowych dochodów, co przyczynia się do poprawy standardu życia mieszkańców obszarów wiejskich, a właściwie realizowana staje się istotną aktywnością w walce o zachowanie środowiska naturalnego [Jalinik 2015]. Ekoagroturystyka odgrywa istotną rolę w realizacji idei zrównoważonego rozwoju, w znaczący sposób przyczyniając się do wzrostu świadomości ekologicznej zarówno turystów, jak i przyjmujących ich gospodarzy. Rosnące zainteresowanie ze strony potencjalnych turystów wypoczynkiem w atestowanych, ekologicznych gospodarstwach rolnych w połączeniu ze wzrastającą świadomością ekologiczną usługodawców sprawia, że w ostatnich latach w Polsce obserwuje się systematyczny wzrost liczby gospodarstw ekoagroturystycznych, a ich rozwój wynika również z faktu, że coraz więcej osób zwraca uwagę na wcześniej zupełnie niedostrzegany problem ekologii [Kuźniar 2013, s. 96; Ciepiela, Balińska 2016]. 
Dla zwiększenia skuteczności prowadzonych przez gospodarstwa ekoagroturystyczne działań marketingowych, które powinny być realizowane z jednej strony z punktu widzenia ograniczania negatywnego wpływu prowadzonej działalności usługowej na środowisko, a z drugiej z uwzględnieniem specyfiki klienta uwrażliwionego na kwestie zdrowego i ekologicznego stylu życia oraz ochrony środowiska, zasadne jest wzięcie pod uwagę w aktywności rynkowej tych gospodarstw koncepcji marketingu ekologicznego, bazującej na rozpoznanych uwarunkowaniach jej realizacji na rynku usług ekoagroturystycznych. Marketing ekologiczny można zdefiniować jako proces odpowiedzialny za kompleksową identyfikację, przewidywanie i zaspokajanie potrzeb poszczególnych konsumentów i społeczeństwa jako całości w sposób przynoszący zyski i równocześnie zapewniający równowagę ekologiczną. Jest on skoncentrowany na środowisku, traktuje środowisko jako coś, co samo w sobie jest głęboką wartością [Esty, Winston 2006, s. 123-130; Grant 2007, s. 32-56; Polonsky, Mintu-Wimsatt (eds.) 2007, s. 6-35]. Realizacja koncepcji marketingu ekologicznego na rynku usług ekoagroturystycznych sprzyja zatem sprawniejszemu pozyskiwaniu klientów, przyczyniając się do rozwoju tego typu działalności usługowej. Aby świadczenie usług turystycznych mogło przynosić właścicielom gospodarstw ekoagroturystycznych satysfakcjonujące ich korzyści, powinni oni zdiagnozować preferencje klientów odnośnie do kształtu stosowanych działań marketingowych w obszarze wykorzystywanych narzędzi marketingowych.

Celem artykułu jest przedstawienie działań marketingowych gospodarstw ekoagroturystycznych w świetle oczekiwań ekoagroturystów, a także sformułowanie dla tych gospodarstw rekomendacji w obszarze realizacji proekologicznej aktywności marketingowej.

\section{Metodyka badań}

Badania zaprezentowane w niniejszym artykule zostały zrealizowane w roku 2012 i 2017. Realizacja badań w roku 2012 nastąpiła w ramach projektu badawczego nr NN115119539 finansowanego przez Narodowe Centrum Nauki. W roku 2017 zaistniała możliwość powtórzenia badań w odniesieniu do wybranych obszarów w ramach szerszego projektu, co wykorzystano do zdiagnozowania ewentualnych zmian, jakie zaszły w zachowaniach marketingowych polskich gospodarstw ekoagroturystycznych na rynku w ciągu pięciu lat, oraz zmian w oczekiwaniach ich klientów, a także do sformułowania rekomendacji dotyczących pożądanego kształtu działań marketingowych gospodarstw ekoagroturystycznych w świetle oczekiwań ekoagroturystów.

W roku 2012 baza danych obejmowała 235 gospodarstw występujących w różnych ewidencjach w momencie rozpoczęcia ich badania pod nazwą ,gospodarstwa ekoagroturystyczne", a respondentami w badaniu tych gospodarstw byli ich właściciele lub współwłaściciele. Baza teleadresowa gospodarstw ekoagroturystycznych została stworzona na podstawie informacji dostępnych w Europejskim Centrum Ekologicznego Rolnictwa i Turystyki (ECEAT) i Centrum Doradztwa Rolnicze- 
go w Brwinowie oraz uzupełniona danymi pochodzącymi z innych źródeł podających tego typu informacje (strony internetowe gospodarstw ekoagroturystycznych, stowarzyszeń agroturystycznych, raporty dotyczące ekoagroturystyki itp.). Po uwzględnieniu zarówno dostępności, jak i zgody właścicieli lub współwłaścicieli gospodarstw ekoagroturystycznych na udział w badaniach, uzyskano 85 wywiadów. W roku 2017, wykorzystując powyższe źródła informacji, zidentyfikowano 286 gospodarstw, a na udział w badaniu wyraziło zgodę 98 gospodarstw. W badaniu gospodarstw ekoagroturystycznych wykorzystano metodę wywiadu w oparciu o technikę, jaką był wywiad telefoniczny z wykorzystaniem standaryzowanego kwestionariusza wywiadu opracowanego przez autorkę niniejszego artykułu.

W badaniu klientów gospodarstw ekoagroturystycznych w latach 2012 i 2017 zbiorowość statystyczną stanowiły osoby wypoczywające w tych gospodarstwach. Ze względu na ograniczony budżet badania, odległą lokalizację od siebie poszczególnych gospodarstw oraz ograniczenia czasowe realizacji badań zdecydowano, że badania zrealizowane w 2012 roku obejmą klientów 35 funkcjonujących gospodarstw ekoagroturystycznych posiadających certyfikat rolnictwa ekologicznego. Doboru próby gospodarstw dokonano za pomocą losowania prostego indywidualnego, polegającego na wyborze z populacji ostatecznych, indywidualnych jednostek badania w sposób bezpośredni, nadając każdej jednostce jednakowe prawdopodobieństwo dostania się do próby [Szreder 2004, s. 69-71]. Ostatecznie uzyskano informacje od klientów 32 gospodarstw ekoagroturystycznych. W obrębie każdego z wylosowanych gospodarstw przeprowadzono wywiady z wypoczywającymi tam klientami według zasady, że badaniu podlegała jedna pełnoletnia osoba $\mathrm{z}$ każdego zajętego pokoju. $\mathrm{W}$ ten sposób uzyskano dane od 128 respondentów. W roku 2017, wykorzystując powyższą metodę doboru próby, przeprowadzono wywiady ze 109 respondentami.

W analizie statystycznej wyników badań wykorzystano metody statystyki opisowej, pozwalające na statystyczny opis badanej zbiorowości.

Badania empiryczne zrealizowane $\mathrm{w}$ odniesieniu do gospodarstw ekoagroturystycznych pozwoliły na określenie, w jakich obszarach ich oferty ekoagroturystycznej i w jaki sposób uwzględniony został jej proekologiczny charakter, natomiast wywiady z klientami tych gospodarstw umożliwiły identyfikację pożądanego kształtu ekologicznych aspektów tej oferty.

\section{Aktywność marketingowa gospodarstw ekoagroturystycznych w świetle oczekiwań ekoagroturystów (wyniki badań)}

Zasadność uwzględnienia koncepcji marketingu ekologicznego w aktywności rynkowej gospodarstw ekoagroturystycznych wynika z faktu, że w świetle zrealizowanych badań większość ekoagroturystów, którzy wybierają wypoczynek w gospodarstwach ekoagroturystycznych, świadomie decyduje się na taką formę wypoczynku ze względu na jej proekologiczny charakter (2012 r. - 64,1\%, 2017 r. - 72,5\%).

Głównym motywem wyboru wypoczynku w gospodarstwie ekoagroturystycznym dla przeważającej większości badanych ekoagroturystów był dostęp do żyw- 
ności wyprodukowanej metodami ekologicznymi. Konkretne gospodarstwa były wybierane przez ekoagroturystów właśnie ze względu na duży udział w menu certyfikowanych i własnych produktów gospodarstwa oraz gospodarstw okolicznych, a także duży udział potraw regionalnych w menu. Stanowiło to także najczęściej deklarowane oczekiwania respondentów w stosunku do gospodarstw ekoagroturystycznych odnośnie do ich pożądanych działań proekologicznych (2012 r. - 87,5\%, 2017 r. $-86,2 \%)$.

Mała liczba certyfikowanych produktów i potraw regionalnych w jadłospisie oraz słabe wykorzystanie własnych owoców i warzyw gospodarstwa lub takich produktów pochodzących z okolicznych gospodarstw były wskazywane w obydwu okresach badawczych jako zasadnicze powody braku pełnej satysfakcji z oferowanej proekologicznej formy wypoczynku. Mimo że w przeważającej większości badanych gospodarstw ekoagroturystycznych deklarowano wykorzystywanie w żywieniu ekoagroturystów produktów żywnościowych wytwarzanych metodami tradycyjnymi we własnym gospodarstwie, to widocznie nie w takim stopniu, który by usatysfakcjonował klientów. Stosunkowo niewielu gospodarzy wzbogacało swoją ofertą żywieniową artykułami żywnościowymi posiadającymi certyfikat ekologiczny, pochodzącymi z innych ekologicznych gospodarstw rolnych (2012 r. - 39\%, 2017 r. - 36,7\%). Natomiast wyraźnie zaznaczyła się w gospodarstwach ekoagroturystycznych tendencja wzrostowa związana $\mathrm{z}$ wykorzystywaniem $\mathrm{w}$ jadłospisie artykułów żywnościowych wytwarzanych metodami tradycyjnymi (2012 r. - 53\%, 2017 r. - 64,3\%). Najlepiej wypadają one jednak w odniesieniu do oferowania ekoagroturystom potraw regionalnych specyficznych dla danego regionu. W tym zakresie występują najmniejsze rozbieżności między oczekiwaniami ekoagroturystów a ofertą gospodarstw.

Mimo że ekoagroturyści postrzegają działania proekologiczne gospodarstwa ekoagroturystycznego przede wszystkim przez pryzmat własnych doraźnych korzyści związanych z dostępem do zdrowej żywności, a nie długofalowych korzyści dla środowiska, będących efektem określonych działań tego gospodarstwa, niezwiązanych bezpośrednio z rolnictwem ekologicznym, to jednak dostrzegają także potrzebę takich działań proekologicznych, wśród których wymieniane były np. segregacja śmieci, różne formy oszczędzania energii czy też wykorzystywanie odnawialnych źródeł energii. Wśród przeważającej większości badanych ekoagroturystów daje się zauważyć duży potencjał chęci bezinteresownych proekologicznych działań w gospodarstwie ekoagroturystycznym (aż 79,7\% w roku 2012 i 83,5\% w roku 2017 ekoagroturystów zgodziłoby się realizować określone działania proekologiczne w gospodarstwie, gdyby stworzono im taką możliwość, nie oczekując z tego tytułu żadnych korzyści rzeczowych lub finansowych). Potencjał ten powinien być przez właścicieli gospodarstw ekoagroturystycznych jak najlepiej spożytkowany z korzyścią dla środowiska poprzez stwarzanie ekoagroturystom jak najwięcej możliwości tego typu działań (np. oszczędzania wody, energii elektrycznej, segregacji śmieci, rezygnacji z wykorzystywania samochodu na rzecz udostępnianych rowerów lub też 
rezygnacji z wykorzystywania standardowych środków piorących na rzecz ekologicznych). Badane gospodarstwa ekoagroturystyczne jednak w dość ograniczonym zakresie realizują dodatkowe, niezwiązane $\mathrm{z}$ rolnictwem ekologicznym, działania proekologiczne i dotyczą one przede wszystkim segregowania odpadów (2012 r. - 88\%, 2017 r. - 89,8\%) oraz w niewielkim stopniu wykorzystania kolektorów słonecznych $(2012$ r. - 26\%, 2017 r. - 32,7\%) czy też biologicznych oczyszczalni ścieków (2012 r. - 24\%, 2017 r. - 41,8\%). Gospodarstwa powinny jednak zdawać sobie sprawę, że ekoagroturysta, jako adresat ich działań marketingowych, staje się coraz bardziej ekologicznie świadomy i jego oczekiwania w odniesieniu do proekologicznych działań gospodarstwa ekoagroturystycznego będą wzrastać, co będzie stymulować konieczność różnicowania i wzbogacania tych działań.

W działalności ekoagroturystycznej, ze względu na jej specyfikę, powinno się przywiązywać dużą wagę do dokumentów potwierdzających angażowanie się gospodarstwa ekoagroturystycznego $\mathrm{w}$ działania na rzecz ochrony środowiska. W roku 2012 istotną rolę odgrywał certyfikat „Czysta Turystyka”. Potwierdziły to badania, według których aż dla $68,8 \%$ respondentów posiadanie tego certyfikatu miało istotne znaczenie przy wyborze oferty ekoagroturystycznej. Równocześnie wśród badanych gospodarstw ekoagroturystycznych posiadanie certyfikatu „Czysta Turystyka” było bardzo słabo rozpowszechnione (miało go tylko 9\% gospodarstw). Ponieważ certyfikat „Czysta Turystyka” został już zamknięty, gospodarstwa ekoagroturystyczne mają możliwość ubiegania się o certyfikat „Ecolabel” oraz „Green Key”. W świetle badań z 2017 roku żadne gospodarstwo nie posiadało jednak wspomnianych certyfikatów związanych z prowadzoną działalnością turystyczną, mimo że certyfikacja w dalszym ciągu była istotnym czynnikiem wyboru gospodarstwa ekoagroturystycznego przez klientów $(65,1 \%)$. Zaleceniem w tym obszarze dla gospodarstw ekoagroturystycznych jest zatem uznanie uzyskania certyfikatów związanych z prowadzoną działalnością turystyczną za istotne z punktu widzenia realizowanej działalności marketingowej.

W działalności marketingowej gospodarstw ekoagroturystycznych istotną rolę odgrywa także System Kwalifikacji i Kategoryzacji Wiejskiej Bazy Noclegowej, który informuje o zapewnieniu przez gospodarstwo odpowiedniego poziomu jakości usługi zakwaterowania. W roku 2012 skategoryzowanych było 52\% badanych gospodarstw, natomiast w roku 2017 zaznaczył się już wyraźny wzrost liczby takich gospodarstw - 69,4\%. Mimo że badani ekoagroturyści w roku 2012 przykładali do kategoryzacji stosunkowo małą wagę (tylko $24,9 \%$ respondentów deklarowało duże i bardzo duże znaczenie kategoryzacji przy wyborze oferty ekoagroturystycznej), to w roku 2017 było to już 46,8\% respondentów. Gospodarstwa ekoagroturystyczne powinny zatem starać się dążyć do otrzymania jak najwyższej kategorii w Systemie Kwalifikacji i Kategoryzacji Wiejskiej Bazy Noclegowej, co będzie sprzyjać pozytywnemu postrzeganiu oferty gospodarstwa na rynku.

Jednym z bardziej istotnych dla ekoagroturystów motywów wyboru oferty gospodarstwa ekoagroturystycznego w obydwu okresach badawczych była chęć aktywnego wypoczynku na wsi, co skutkowało wyborem takich gospodarstw, które 
w swojej ofercie miały również szeroki wachlarz atrakcji dodatkowych, związanych bezpośrednio z ekologicznym aspektem oferty, takich jak udział w warsztatach i ścieżkach dydaktycznych promujących ekologiczny styl życia, pokaz i nauka pieczenia chleba według tradycyjnej receptury, udział w warsztatach na temat korzyści z wykorzystania produktów pszczelich, nauka przygotowywania potraw regionalnych tradycyjnymi metodami czy też wycieczki do miejsc umożliwiających obserwowanie i fotografowanie ptaków i zwierząt. Gospodarstwa powinny zatem dążyć do rozszerzania liczby oferowanych proekologicznych atrakcji dodatkowych tak, aby każdy z ekoagroturystów mógł skomponować z nich najbardziej odpowiadający mu zestaw, w czym pomocne powinny być sugestie samych ekoagroturystów gromadzone w procesie ich ankietyzacji przez właścicieli gospodarstw ekoagroturystycznych.

Działalność marketingowa gospodarstw ekoagroturystycznych zdeterminowana jest również prowadzeniem przez nie właściwej polityki cenowej w obszarze świadczonych usług. Zdaniem zarówno ekoagroturystów, jak i właścicieli gospodarstw ekoagroturystycznych ceny oferty ekoagroturystycznej, świadczonej w ekologicznym gospodarstwie rolnym, są porównywalne do cen ofert agroturystycznych. Równocześnie jednak jednym z powodów braku satysfakcji ekoagroturystów z oferowanej proekologicznej formy wypoczynku była ich zdaniem zbyt wysoka cena w stosunku do poziomu uwzględnienia jej ekologicznych aspektów (2012 r. - 18,9\%, 2017 r. $31,2 \%$ ), co podkreśla znaczenie tych aspektów dla klientów. Istotne jest również to, że większość ankietowanych turystów nie chciałaby płacić wyższej ceny za pobyt z powodu umożliwienia im uwzględnienia większej liczby certyfikowanych produktów ekologicznych w posiłkach, co było bardziej zauważalne w badaniach realizowanych w 2017 roku (2012 r. - 57\%, 2017 r. - 71,6\%), oczekując równocześnie, aby ich liczba w menu była jak największa. Dostęp do żywności wyprodukowanej metodami ekologicznymi był najistotniejszym powodem wyboru gospodarstwa ekoagroturystycznego, a większość ekoagroturystów nie chciała ponosić dodatkowych kosztów związanych z ewentualnym umożliwianiem im indywidualnego wzbogacania menu o dodatkowe produkty ekologiczne. W związku z tym zaleceniem dla gospodarstw ekoagroturystycznych w odniesieniu do wykorzystywanych w wyżywieniu ekoagroturystów produktów żywnościowych jest stałe dążenie do zwiększania w nim udziału produktów certyfikowanych oraz produktów wytwarzanych metodami tradycyjnymi, pozyskiwanych również w ramach współpracy z pobliskimi gospodarstwami rolnymi (co może również przyczynić się do rozwoju proekologicznych działań tych gospodarstw w obszarze ich produkcji rolnej). Gospodarstwa ekoagroturystyczne powinny także starać się uwzględniać w swoim menu jak najwięcej potraw regionalnych przygotowywanych według tradycyjnych receptur, co przyczynia się do zachowania oryginalnego charakteru kulturowego danego regionu.

W marketingowej aktywności gospodarstw ekoagroturystycznych istotną rolę w procesie pozyskiwania klientów odgrywają działania promocyjne, które powinny być realizowane w taki sposób, aby potencjalni klienci otrzymywali na tyle wyczerpujące informacje o ofercie ekoagroturystycznej, aby przyczyniły się do jej wyboru 
spośród dostępnych alternatyw. Badani ekoagroturyści jako podstawowe źródło informacji o ofercie ekoagroturystycznej wymieniali przede wszystkim stronę internetową gospodarstwa (2012 r. - 90,6\%, 2017 r. - 95,4\%). Dla wielu respondentów motywem wyboru konkretnego gospodarstwa był interesujący sposób przedstawienia oferty na jego stronie internetowej. Ponad połowa badanych w obydwu okresach badawczych jako źródło informacji o ofercie ekoagroturystycznej wskazywała również stronę Europejskiego Centrum Rolnictwa Ekologicznego i Turystyki ECEAT. Gospodarstwa ekoagroturystyczne powinny więc zadbać o stworzenie własnej atrakcyjnej strony internetowej oraz o jej wysokie pozycjonowanie w wyszukiwarkach, a informacje na niej zawarte powinny wyczerpująco i w sposób interesujący eksponować specyfikę oferty ze szczególnym uwzględnieniem jej ekologicznych aspektów. Gospodarstwa ekoagroturystyczne powinny również dążyć do członkostwa w Europejskim Centrum Rolnictwa Ekologicznego i Turystyki ECEAT, co skutkuje możliwością umieszczenia swojej oferty ekoagroturystycznej na stronach tej organizacji.

Istotną rolę w promowaniu oferty ekoagroturystycznej odgrywa informowanie przebywających w gospodarstwie ekoagroturystycznym klientów o obecnych i planowanych proekologicznych działaniach gospodarstwa. Może to skutkować nie tylko ich powtórnym przyjazdem do gospodarstwa, ale także pozyskaniem nowych klientów w drodze rekomendacji. Informacje takie chciałoby uzyskiwać coraz więcej badanych ekoagroturystów ( 2012 r. - 60\%, 2017 r. - 74,3\%), a jako ich pożądane źródło wskazywano przede wszystkim bezpośrednie spotkania informacyjne z właścicielem lub personelem gospodarstwa oraz materiały informacyjne dostępne w gospodarstwie. Również ponad połowa badanych ekoagroturystów byłaby zainteresowana, po zakończeniu pobytu w gospodarstwie, otrzymywaniem informacji dotyczących aktualizacji oferty gospodarstwa ekoagroturystycznego z punktu widzenia poprawy jej ekologicznego charakteru. Gospodarstwa ekoagroturystyczne powinny starać się realizować te oczekiwania, co może przyczynić się do budowania lojalności ich klientów. Ważnym elementem działań promocyjnych gospodarstwa ekoagroturystycznego są drukowane materiały promocyjne, w których powinny być podkreślane wszystkie działania gospodarstwa sprzyjające ochronie środowiska. Aktywność promocyjna gospodarstw ekoagroturystycznych powinna również uwzględniać udział w imprezach promujących ekologiczny styl życia i lokalne dziedzictwo kulturowe, co może sprzyjać popularyzowaniu ekoagroturystyki jako formy wypoczynku.

Wśród wymagań stawianych pracownikom mającym bezpośredni kontakt z klientem najważniejsze dla badanych ekoagroturystów było posiadanie szczegółowej wiedzy o oferowanych w gospodarstwie produktach ekologicznych oraz wdrażanych w nim aktualnych i planowanych działaniach proekologicznych. Równocześnie w badanych gospodarstwach wiedzę tę posiadali jednak najczęściej wyłącznie właściciele. Zasadne jest więc udostępnienie jej wszystkim pracownikom mającym kontakt $\mathrm{z}$ klientem. Istotne $\mathrm{z}$ punktu widzenia ekoagroturystów było także szybkie i elastyczne reagowanie na indywidualne potrzeby klientów. Zaleceniem dla gospo- 
darstw ekoagroturystycznych jest więc organizowanie przez właścicieli okresowych zebrań z personelem w celu analizowania i rozwiązywania bieżąco występujących problemów (ponad połowa właścicieli badanych gospodarstw ekoagroturystycznych nie organizuje wcale tego typu spotkań).

Aby zagwarantować zgodność oferty ekoagroturystycznej z wymaganiami klientów, ważne jest doskonalenie przez gospodarstwa ekoagroturystyczne oferty z punktu widzenia jej ekologicznych aspektów. Może przyczyniać się do tego badanie klientów w tym obszarze realizowane przez właścicieli gospodarstw ekoagroturystycznych. Przeważająca większość badanych gospodarstw nie ankietuje swoich klientów na temat świadczonych usług, a wśród ankietujących tylko połowa uwzględnia w swoich ankietach pytania umożliwiające wyrażenie opinii na temat proekologicznych aspektów oferty. Ponieważ jednak w obydwu okresach badawczych ekoagroturyści w przeważającej większości chcieliby mieć swój udział w doskonaleniu proekologicznych aspektów oferty ekoagroturystycznej poprzez wypełnianie ankiety udostępnianej w gospodarstwie (2012 r. - 89,1\%, 2017 r. - 93,6\%), zaleceniem dla właścicieli gospodarstw ekoagroturystycznych jest stosowanie ankietyzacji ekoagroturystów w procesie kreowania jak najlepszej proekologicznej oferty usługowej, z jak najszerszym uwzględnieniem pytań dotyczących jej ekologicznych aspektów.

\section{Zakończenie}

Działalność ekoagroturystyczna realizowana w ekologicznych gospodarstwach rolnych generuje korzyści zarówno dla samych gospodarstw, ze względu na możliwość uzyskania dodatkowych zysków z działalności turystycznej, jak i dla klientów poszukujących oferty wypoczynkowej, która będzie ich satysfakcjonować w zakresie jej ekologicznych aspektów. Zasadne jest więc, aby działalność marketingowa gospodarstw ekoagroturystycznych była zgodna z koncepcją marketingu ekologicznego. Oferowane wyżywienie powinno uwzględniać jak największy udział produktów certyfikowanych oraz produktów wytwarzanych metodami tradycyjnymi, pozyskiwanych również w ramach współpracy z sąsiednimi gospodarstwami rolnymi. Ekoagroturyści powinni mieć możliwość uczestnictwa w zróżnicowanych proekologicznych działaniach realizowanych w gospodarstwie. Należy dążyć do rozszerzenia liczby oferowanych ekoagroturystom atrakcji dodatkowych, związanych bezpośrednio z ekologicznych aspektem oferty tak, aby mogli oni dokonać indywidualizacji nabywanej oferty zgodnie ze swoimi potrzebami. Cena oferty gospodarstwa ekoagroturystycznego powinna być przede wszystkim adekwatna do stopnia uwzględnienia w niej aspektów proekologicznych. W związku ze specyfiką usług ekoagroturystycznych zasadne jest podkreślanie w działaniach promocyjnych gospodarstw ekoagroturystycznych proekologicznych aspektów ich działalności. Konieczne jest także podejmowanie wysiłków zmierzających do uzyskania certyfikatów związanych z prowadzoną działalnością turystyczną oraz podkreślanie ich posiadania 
w prowadzonych działaniach promocyjnych. W celu jak najlepszego dostosowania usług ekoagroturystycznych do potrzeb segmentu docelowego należy również dokonywać okresowej ankietyzacji ekoagroturystów z jak najszerszym uwzględnieniem pytań dotyczących ekologicznych cech oferty, co pozwoli na jej doskonalenie.

Ponieważ wzrastająca świadomość społeczna w odniesieniu do problemów związanych z ochroną środowiska skutkować będzie również zmianami w ofercie turystycznej [Ministerstwo Sportu i Turystyki 2015], przedstawione w artykule rekomendacje dotyczące działań marketingowych gospodarstw ekoagroturystycznych mogą być pomocne w ich funkcjonowaniu na rynku.

\section{Literatura}

Ciepiela G.A., Balińska A., 2016, Wykorzystanie zasobów ziemi i kierunki rozdysponowania produkcji rolniczej w gospodarstwach ekoagroturystycznych położonych na terenie Polski Wschodniej, Zeszyty Naukowe Wyższej Szkoły Turystyki i Ekologii w Suchej Beskidzkiej, nr 2, s. 26-48.

Czerwińska-Jaśkiewicz M., 2013, Marketing w agroturystyce. Ujęcie segmentacyjne, Difin, Warszawa. Esty D.C., Winston A.S., 2006, Green to Gold: How Smart Companies Use Environmental Strategy to Innovate, Create Value, and Build Competitive Advantage, Yale University Press, New Heaven.

Grant J., 2007, The Green Marketing Manifesto, John Wiley \& Sons, Chichester.

Jalinik M., 2009, Uwarunkowania i czynniki rozwoju ustug turystycznych na obszarach wiejskich, Oficyna Wydawnicza Politechniki Białostockiej, Białystok.

Jalinik M., 2015, Antropopresja w ekoagroturystyce, Ekonomia i Środowisko, nr 3, s. 192-199.

Kuźniar W., 2013, Aktywność marketingowa gmin i jej oddziaływanie na rozwój turystyki, Wydawnictwo Uniwersytetu Rzeszowskiego, Rzeszów.

Ministerstwo Sportu i Turystyki, 2015, Program Rozwoju Turystyki do 2020 roku, https://bip.msit.gov. $\mathrm{pl} /$ bip/projekty-aktow-prawnyc/zakonczony-proces-legi/inne/1599, Program-Rozwoju-Turystyki-do-2020-roku.html (29.04.2018).

Pałka E., 2015, Uwarunkowania i procesy rozwoju agroturystyki. Przykład województwa świętokrzyskiego, Wydawnictwo Uniwersytetu Jana Kochanowskiego, Kielce.

Polonsky J.M., Mintu-Wimsatt A.T. (eds.), 2007, Environmental Marketing, The Haworth Press, New York.

Privitera D., 2010, The importance of organic agriculture in tourism rural, Applied Studies in Agribusiness and Commerce (Abstract), vol. 4, no. 1-2, s. 59-64.

Romankiewicz B., Krupa J., 2013, Rolnictwo ekologiczne czynnikiem zwiększenia oferty turystycznej w województwie podkarpackim, [w:] Krupa J. (red.), Ochrona środowiska, krajobraz przyrodniczy i kulturowy Pogórza Dynowskiego a rozwój turystyki, Związek Gmin Turystycznych Pogórza Dynowskiego, Dynów, s. 149-159.

Rozporządzenie Rady (WE) nr 834/2007 z dnia 28 czerwca 2007r. w sprawie produkcji ekologicznej i znakowania produktów ekologicznych i uchylającego rozporządzenie (EWG) nr 2092/91, https:// eur-lex.europa.eu/legal-content/PL/TXT/?uri=CELEX\%3A32007R0834 (29.04.2018).

Sikora J., Wartecka-Ważyńska A., 2013, Wybrane uwarunkowania turystyki wiejskiej, Bogucki Wydawnictwo Naukowe, Poznań.

Szreder M., 2004, Metody i techniki sondażowych badań opinii, PWE, Warszawa. 